\title{
Improving the Quality of Tutorials to Create a Quality Culture Through an Integrative Selection of Tutors
}

\author{
T Setyowati ${ }^{1}$, R Setiani ${ }^{2}$, D Sambada ${ }^{1}$, W A Surasmi ${ }^{1}$, ${ }^{*}$ Dwikoranto $^{3}$ \\ 1UPBJJ-UT Surabaya, Open University Surabaya, Campus C Mulyorejo Unair 60115, Indonesia \\ 2Bhinneka PGRI University of Tulungagung, Jl. Mayor Sujadi Timur No.7, Ploso Kandang, Tulungagung 66221, \\ Indonesia \\ ${ }^{3}$ Department of Physics, Faculty of Mathematics and Natural Science, Universitas Negeri Surabaya, Surabaya 60231, \\ Indonesia
}

\section{Article Info}

Article history:

Received July 13, 2020

Revised November 18, 2020

Accepted November 29, 2020

Available Online December 6, 2020

\section{Keywords:}

Improving

Integrative

Quality

Quality culture

Tutorial

\begin{abstract}
Open University is needed to meet the needs of studying without being limited by space, time, amount, cost, age, and distance with a quality tutor. This study aims to describe the ideal form of tutor recruitment, the role of tutors and get quality tutors. This survey research was conducted at the Distance Learning Program Unit (DLPU) Surabaya with data collection methods through observation, interviews, questionnaires and documentation. Sources of data were obtained from Study groups, Tutors, Department of Education, Regional Responsibility in the tutorial period 2019.1 and 2019.2. Data were analyzed descriptively. The results showed that: (1) The ideal form of tutor recruitment is through tutor selection, through the tutor candidate test, through agency recommendations and special offers. (2) The role of tutors in the professional learning process is that tutors are still needed for certain subjects, as innovators and motivators, to play a role in reducing dropout. (3) To get quality tutors and not only as a parttime job so that tutors in working remain professional is to build a sound system. The obligations and rewards that are received appropriately. Between taxes and a decent income. Also, between expertise or rank need to be adjusted to the level of compensation which is given.
\end{abstract}

\section{INTRODUCTION}

Based on the Minister of Education and Culture regarding the implementation of distance education, it is stated that DLPU-OU is a unit of distance learning programs in the region, in the implementation of distance learning systems. The characteristics of distance education applied by the Open University (OU) require students to study independently and be proactive in their studies. Students must have the discipline to manage time, study, make priorities learn teaching materials, overcome problems and learning difficulties quickly and independently. In the distance learning system (DLS), OU provides various services, learning resources for students such as printed materials, online teaching materials, non-printed teaching materials, which are designed for independent learning (Belawati \& Darojat, 2012). Face to face tutorials (FFT), Online Tutorials (Tuton), and self-training (ST) are facilities obtained by students. Open University is, open, long distance, without age limit, practical, efficient, inexpensive, affordable, unlimited number of participants, the location can be anywhere, anytime, under any circumstances (Open University, 2015a; 2015b). For the implementation of OU in the regions, OU cooperates with various government and private institutions such as the Department of 
Education, Islamic Boarding Schools, Ministry of Religion, Islamic Education Foundations, Educational Foundations, Schools, State Universities and Private Universities. The OU partnership network has been going on for a long time since the institution was established on September 4, 1984 and guaranteed by law, in the context of empowering human resources in regions that have not been able to get further study opportunities due to limited time, distance, cost and age. With the presence of $\mathrm{OU}$ it is expected that the obstacles of citizens studying studies can be overcome, throughout Indonesia, so that people can learn to improve quality and cultured human resources. To bridge the communication between students and OU, regional learning service centers are being formed which are coordinated by the local Education Office by forming learning groups (LG). LG is a collection of OU students who build commitment and mutual agreement to help each other and mutually support the smooth and successful learning in OU with or without other party facilities (Guidelines for LG OU, JKPP KBOO, 2017). LGs can form independent LGs, DLPU-OU LGs, at the initiative of students independently and are chaired by students. The principle of benefits, namely for facilitate learning group activities and communication between LG and DLPU-OU, while accessibility of services, namely to bring OU services closer to study groups. The LG administrator is appointed and dismissed by the head of DLS-OU Surabaya.

In the framework of optimally providing education services to students, OU cooperates with other institutions such as state and private universities, Bank Mandiri, Bank BRI, Bank BTN, Sky LBS, Radio Republik Indonesia (RRI), Regional Broadcast Radio, National Private Radio, Provincial Governments, Regency and City Governments. The Regional Library, Kindergarten Teachers Association, OU also collaborates with Microsoft 365 to provide convenient services to students in using 365 software that is provided online. Collaborate with Telkom by using high-speed broadband access network services for free in various regions (Simamora, 2003). The Department of Education, local governments are following programs in $\mathrm{OU}$, or designing special training programs according to their needs, also gaining the trust of government level I and level II to improve the quality of elementary school teachers and kindergarten teachers taking the S-1 Teacher education program. Starting in 2015 OU is working with PT. Dwi Guna Cipta Nusantara is a subsidiary of Limited company. Telkom to hold OU or SAL-OU service centers, which are located in regions throughout Indonesia. Institutions such as OU cannot be separated from the work of the partnership system with stakeholders, government agencies, banking institutions as well as community institutions, educational institutions. Because $\mathrm{OU}$ is set to be able to reach the entire Indonesian community in increasing human resources, because the model, the form of institutions such as OU can reach the wider community, unlimited time, open, cheap, practical, efficient. On November 19, 2017, in his opening remarks at IX at UTCC Jakarta, the Minister of National Education hoped that OU students can reach 1 million students. It is appropriate that OU can empower the quality of human resources in educational institutions in realizing a quality culture in partnership, in collaboration, institutionally. One important component in the distance learning system (DLS) is the role of the tutor in the teaching and learning process in the tutorial (Moore \& Kearsley, 2012). It becomes a tutor, various requirements must be met by an applicant who wishes to become a tutor, with a minimum requirement of obtaining an S2 certificate with BAN PT accreditation with a B grade.

So far, OU tutors come from various public or private tertiary institutions, while OU lecturers are only allowed through the online tutorial if they want to teach at OU. Because they come from various tertiary educational backgrounds and in general these tutors have become permanent civil servants at their respective colleges or schools. It results in the motivation to become a tutor, the initial intention to become a tutor as a part-time job, or side jobs, as a result, some tutors are half-hearted, lacking discipline, not optimal in the tutorial. Various cases originating from tutors are numerous such as collecting late assignments, making copy paste grades, not being disciplined in carrying out their duties as tutors. Paying attention to cases that occur in the behavior of tutors, it is necessary to improve the method for recruiting tutors by 
paying attention to academic factors as well as administrative factors, if necessary, the psychology.

This study discusses how to recruit qualified tutors so that in the future it will not disadvantage students or OU institutionally, so that the impression of side jobs, additional work can be avoided. For this purpose, this research relates to integrative tutor selection in order to get quality tutors. Integrative in the study that in the context of research between academic tutor requirements in the form of diplomas, State universities/private universities accreditation status is really examined, besides supporting factors such as certificates, Lecturer/Teacher Characteristics certificates, research/scientific work certificates, research works and lecturer status on State universities/private universities. While the administrative completeness of lecturers, prospective lecturers should be considered. List of Lecturers' CVs, Lecturers Research History, Lecturer staffing history, and Psychology interviews with prospective tutors.

With an integrative selection of the various requirements needed to get a Tutor ID, it is expected that the quality of OU tutors is good despite coming from various institutions. So that the impression of OU Tutors is a side job by lecturers, teachers, and practitioners can be avoided. Tutors are a source of knowledge for students because of their function of delivering the material (Craig et al., 2008) or the teacher must have good academic, administrative and physical psychology qualities, before becoming a tutor, this aims to create a culture of academic quality in each OU tutor.

The research objectives are as follows.

1. Know the ideal form or method of tutor recruitment so that all teacher quality improvement programs are successful and run well.

2. Describe the role of the tutor in the professional learning process in the tutorial activities carried out.

3. Describe how to get a quality tutor so that becoming a tutor at $\mathrm{OU}$ is not just an additional job so that the tutor in working remains professional.

Benefits of Research

1. Creating Human Resources as OU Quality Tutors to carry out the tutorial.

2. Creating a quality tutorial so that it impacts on the results of good performance towards OU students and becomes smart.

This research starts with the assumption that the need for academically qualified tutors is relevant to the field of study, majors, academic improvement for tutors is needed so that professional tutors are reached (Meilani, 2008). So that qualified and professional tutors, in someone contain the most profound and different meaning in each individual. Therefore, studying tutor behavior requires theoretical tools such as Weber's social action theory (Mannes, 1977; Anthony \& Turner, 2015), to explore the things needed to create quality tutors. The paradigm of social facts, seeing that the quality of a tutor is determined by external factors that are forced and controlling individuals. The social definition paradigm emphasizes actions based on subjective meanings. Good tutor behavior will positively repeat when getting the expected reward, on the contrary non-repetitive behavior when the behavior of the person gives birth to a punishment that is greater than the reward. The repetition of a person's social actions such as a tutor is highly dependent on repetition or similarities that existed and were obtained in the past (Mead, 2012).

To improve the quality of tutors there must be social tutor actions in giving tutorials, assessing students at the time of the tutorial, and reporting the results of the tutorial transparently, because in order to determine that qualified tutors, both Basic education and non-basic education are DLS-OU with the holding of strict, effective selection, high accountability through integral selection. Tutors with good quality human resources will improve the quality of the process in the tutorial so that it significantly influences student achievement, and the Open University as an institution (Sugiran et al., 2016). 


\section{RESEARCH METHOD}

Based on the research object, both the place and the source of the data, this research is included in the survey research, this survey research is mainly based on research in the field or field (Bogdan \& Biklen, 1998). This research was conducted with a Phenomenology approach, meaning 1) subjective experience or phenomenological experience from someone and 2) a study of awareness and main perspectives from someone (Moleong, 2014). This type of research is qualitative, namely research that intends to understand the phenomena about what is experienced by the subject, example research into behavior, perception, motivation, action, holistically by means of descriptions in the form of words and language, in a particular context naturally with utilizing various natural methods. Descriptive research is a study that seeks to gather information about a theme, symptom or circumstance according to what it is to find the widest possible knowledge of the object of research. Descriptive research is generally carried out with the main objective, namely to systematically describe the facts and characteristics of the object or subject being examined precisely (Muhajir, 2013).

This research was carried out in DLPU-OU Surabaya because as follows: (1) Surabaya DLPU-OU has a wide area, namely 18 districts/cities (2) employees, employees, teachers with a large number of hours and needs to be improved specifically for senior high school education. (3) with integral collaboration between institutions, it is expected that HR in East Java will have academic quality that matches the minimum problems of Bachelor degree.

Research data sources: (1) To explain the program to improve the quality of education, researchers conducted interviews, observations, documentations with tutors who gave tutorials at DLPU-OU Surabaya. (2) To explain the implementation of improving the quality of tutors in the tutorial, the researcher conducted interviews, observations, and through available documentation, which was conducted with informants. This data relates to improving the quality of tutors at DLPU-OU Surabaya by conducting in-depth interviews, observations and through documentation. (3) To explain the inhibiting and supporting factors for improving the academic quality of the community, researchers conducted interviews, observations, or through documentation with, ranks of managers, study groups, OU tutors, OU administration employees.

Data collection techniques are a strategic step in research. According to (Sugiyono, 2006), data collection can be done in various settings, various sources and various ways. While in terms of data collection, data collection can be done using interviews, observations, documentation and questionnaires. Based on data sources, data collection can use primary sources and secondary sources. As for what is meant by primary sources is the main source in data collection namely the tutor who gives a tutorial at DLPU-OU Surabaya. Whereas secondary data comes from managers, study groups and regional authorities. The data processing model used in this study uses the Interactive model of Miles and Huberman, namely: data collection, data reduction, data display and conclusion drawing/verification (Miles \& Huberman, 2012; Sabadie et al., 2014).

\section{RESULTS AND DISCUSSION}

After a review of the data obtained during the study both from LG managers, DLPU-OU, Tutors, Regional Responsibility (RR), students and related education practitioners, the following results are obtained.

\section{The ideal form of tutor recruitment so that all teacher quality improvement programs are successful and run well}

The ideal form of tutor recruitment in DLPU-OU Surabaya is that all teacher quality improvement programs are successful and run well from the total number of respondents as many as 40 people are presented as in Table 1 below. 
Table 1. Forms of Tutor Recruitment

\begin{tabular}{|c|c|c|c|c|}
\hline \multirow{2}{*}{ Component } & \multicolumn{2}{|c|}{ Response Yes } & \multicolumn{2}{|c|}{ Response No } \\
\hline & Sum & $\%$ & Sum & $\%$ \\
\hline \multicolumn{5}{|l|}{ 1. Through tutor selection } \\
\hline a. Academic Qualifications & 38 & 95 & 2 & 5 \\
\hline b. Administration requirements & 28 & 70 & 12 & 30 \\
\hline c. Daily Activities & 20 & 50 & 20 & 50 \\
\hline \multicolumn{5}{|l|}{ 2. Through the prospective tutor test } \\
\hline $\begin{array}{l}\text { a. Selection through tests should enter into civil } \\
\text { servants/employees }\end{array}$ & 24 & 60 & 16 & 40 \\
\hline b. Through training prospective tutors & 36 & 90 & 4 & 10 \\
\hline \multicolumn{5}{|l|}{ 3. Through Agency Recommendations } \\
\hline a. Based on work performance & 36 & 90 & 4 & 10 \\
\hline b. Based on the needs of prospective tutors & 36 & 90 & 4 & 10 \\
\hline c. On request & 20 & 50 & 20 & 50 \\
\hline \multicolumn{5}{|l|}{ 4. Through special offers } \\
\hline a. Certain subjects & 32 & 80 & 8 & 20 \\
\hline b. Resource Limitations & 36 & 90 & 4 & 10 \\
\hline
\end{tabular}

Based on Table 1, there are 4 (four) important components in recruiting tutors to increase the quality of teachers who become OU students.

1. Through tutor selection

a. Academically, with the standard quality of lecturers with doctoral degrees, master's and bachelor degrees who are still taking lectures, even there are a number of Professor emeritus who are still committed to giving tutorials at OU.

b. The administration is in the form of completeness of Tutor data: a photocopy of diploma, name, place of birth date, tutor id, identity card, institution of work, number. WA/HP, Email, NPWP, type of financial deposit/transfer bank.

c. Activities/preoccupations: as dean, vice dean, emeritus professor, education observer, state universities and private universities lecturers, lecturers, teachers, staff and employees of education offices, business people, health experts.

2. Through the Prospective Tutor Test

a. Selection through tests should be entered into a particular civil servant/employee. This has not been done for regular tutors, except those who will be civil servants or teacher. This is in accordance with research from Sugiran et al., (2016).

b. Through the training of prospective tutors, after being collected and trained, a capable person will be selected and meet certain criteria. This is relevant to the policies carried out by DLPU-OU Surabaya routinely at the beginning of the registration period (DLPU-OU Surabaya)

3. Through Agency Recommendations

Associated with the OU Tutorial activities with certain conditions mutually agreed according to OU's needs. The education office in partnership with the management of the study group can provide recommendations to existing staff/education personnel and meet the requirements to be submitted as prospective tutors, which will then be tutored.

4. Through special offers

For unique, rare or high-difficulty subjects, DLPU-OU Surabaya staff offers staff who are suited to the course.

The need for qualified academic tutors is relevant to the field of study, majors, academic improvement for tutors is needed so that professional tutors are achieved. So that qualified and 
professional tutors, in someone contains the most profound and different meanings for each individual (Salim, 2011).

From the theoretical framework above it can be explained that to improve the quality of tutors there must be social tutor actions in giving tutorials, assessing students at the time of the tutorial, and reporting the results of the tutorial transparently, because in order to determine that qualified tutors, both the non-recipient and non-recipient are DLPU-OU with holding selection in a tight, effective, high accountability through integral selection (Sugiran et al., 2016). Tutors with good quality human resources will make teaching and learning process quality increase in the tutorial so that it significantly influences student achievement, and Open University as an institution (Siemens, 2005).

\section{The role of the tutor in the professional learning process in the tutorial activities undertaken.}

The results of an investigation into the role of tutors in the professional learning process in tutorial activities conducted in the tutorial class are presented in Table 2 below.

Table 2. Role of the Tutor in the Tutorial

\begin{tabular}{|c|c|c|c|c|c|c|c|c|c|}
\hline \multirow{3}{*}{ No } & \multirow{3}{*}{ Role Description } & \multicolumn{8}{|c|}{ Data Source } \\
\hline & & \multicolumn{2}{|c|}{$\mathbf{S G}^{\mathrm{a}}$} & \multicolumn{2}{|c|}{ Lecturer } & \multicolumn{2}{|c|}{$\mathbf{E A}^{\mathrm{b}}$} & \multicolumn{2}{|c|}{$\mathbf{R R}^{\mathrm{c}}$} \\
\hline & & $\Sigma^{\mathrm{d}}=\mathbf{8}$ & $\%$ & $\Sigma^{\mathrm{d}}=\mathbf{4 0}$ & $\%$ & $\Sigma^{\mathrm{d}}=6$ & $\%$ & $\Sigma^{\mathrm{d}}=\mathbf{8}$ & $\%$ \\
\hline \multirow[t]{5}{*}{1} & a. Still needed for tutorial & 8 & 100 & 40 & 100 & 6 & 100 & 8 & 100 \\
\hline & b. Still needed for essential subject & 8 & 100 & 40 & 100 & 6 & 100 & 8 & 100 \\
\hline & $\begin{array}{l}\text { c. Very necessary for the Court subject } \\
\text { practice/Practicum }\end{array}$ & 6 & 75 & 40 & 100 & 6 & 100 & 8 & 100 \\
\hline & d. Very necessary to scientific work & 8 & 100 & 40 & 100 & 6 & 100 & 8 & 100 \\
\hline & e. Very necessary to program final project & 8 & 100 & 40 & 100 & 6 & 100 & 8 & 100 \\
\hline \multirow[t]{3}{*}{2} & a. Innovation in tutorial practice & 6 & 75 & 36 & 90 & 6 & 100 & 6 & 75 \\
\hline & b. Innovation in learning models & 6 & 75 & 32 & 80 & 6 & 100 & 6 & 75 \\
\hline & c. Innovation in learning media & 6 & 75 & 32 & 80 & 6 & 100 & 6 & 75 \\
\hline 3 & $\begin{array}{l}\text { Tutors play a role in reducing student } \\
\text { dropouts }\end{array}$ & 4 & 50 & 28 & 70 & 4 & 67 & 6 & 75 \\
\hline 4 & The tutor acts as a motivator & 8 & 100 & 40 & 100 & 6 & 100 & 8 & 100 \\
\hline
\end{tabular}

aStudy Group

bEducation Authorities

cRegional Responsibility

dNumber of respondents

Based on Table 2, then,

1. Tutors are still needed in the tutorial process for certain subjects by looking at credits and the level of difficulty and complexity of the course. Statistics Subjects, Basic Concepts of Natural Sciences in Elementary Schools, Computers in Learning, Natural Sciences Learning in Elementary Schools, Basic Mathematical Concepts, and the like still need stabilization from Tutors. Practical subjects, such as Science Practicum in elementary school, and the like require guidance and direction from tutors (Open University, 2005; Open University, 2016).

2. Innovation in teaching or giving important tutorials and should be appreciated by OU as an increase in Tutor motivation. Students feel happy with tutors who innovate and pay more attention to the lectures they teach (Teguh, 2016; Darojat \& Belawati, 2017).

3. Tutors can play a role in reducing the dropout of students by providing motivation and accompaniment to certain student cases. Tutors who empathize with student problems that impact their tutorial activities are quite instrumental in reducing problematic student dropouts.

4. Tutors as motivators for OU students who show symptoms of slowing down the length of time of study, the frequency of student attendance decreases, resulting in an increase or recovery of motivation for students. As a motivator, the tutor overrides the problems that he faces himself and does not bring him into the classroom (Harirotunnadhiroh, 2013). 
3. How to get quality tutors so that becoming a tutor at $\mathrm{OU}$ is not just an additional job so that the tutor in working remains professional.

The responses obtained from SG amounted to 8 people, as many as 40 people Tutors, related Education Office as many as 6 people and Regional Personnel in DLPU-OU Surabaya environment as many as 8 people obtained the results as in Table 3 below.

Table 3. Dominant factors affecting Tutor Character

\begin{tabular}{|c|c|c|c|c|c|c|c|c|}
\hline \multirow{3}{*}{ Description } & \multicolumn{8}{|c|}{ Data Source } \\
\hline & \multicolumn{2}{|c|}{$\mathrm{SG}^{\mathrm{a}}$} & \multicolumn{2}{|c|}{ Lecturer } & \multicolumn{2}{|c|}{$\mathbf{E A}^{\mathrm{b}}$} & \multicolumn{2}{|c|}{$\mathbf{R}^{\mathrm{c}}$} \\
\hline & $\Sigma^{\mathrm{d}}=8$ & $\%$ & $\Sigma^{\mathrm{d}}=40$ & $\%$ & $\Sigma^{\mathrm{d}}=\mathbf{8}$ & $\%$ & $\Sigma^{\mathrm{d}}=40$ & $\%$ \\
\hline Building a standard system & 6 & 75 & 40 & 100 & 6 & 100 & 8 & 100 \\
\hline Appropriate rights and obligations & 8 & 100 & 40 & 100 & 6 & 100 & 8 & 100 \\
\hline $\begin{array}{l}\text { The amount of the Honor and Tax is } \\
\text { appropriate Rank class }\end{array}$ & 8 & 100 & 40 & 100 & 6 & 100 & 8 & 100 \\
\hline $\begin{array}{l}\text { Pay attention to the Zone far/near the tutorial } \\
\text { is adjusted for honorarium }\end{array}$ & 8 & 100 & 40 & 100 & 6 & 100 & 8 & 100 \\
\hline $\begin{array}{l}\text { aStudy Group } \\
\text { bEducation Authorities } \\
\text { cRegional Responsibility }\end{array}$ & & & & & & & & \\
\hline dNumber of respondents & & & & & & & & \\
\hline
\end{tabular}

Based on Table 3, to get a quality Tutor so that becoming a Tutor at OU is not just an additional job so that the tutor in working remains professional is to build a good system. A person will work well if there is a clear system or mechanism, between obligations and rewards that are received properly, between taxes and reasonable income, between skills or rank ranks need to be adjusted to the level of reward given. Many factors at least the choice of work for tutors also contributed attitudes toward the stigma tutor at OU as additional work. The nominative factor of the amount of reward and transport received by the tutor also contributes to the attitude of the tutor stigma at OU as additional work (Darojat \& Belawati, 2014).

Weber's theory of social action implies: to explore the things needed in order to create quality tutors. The paradigm of social facts, seeing that the quality of a tutor is determined by external factors that are forced and controlling individuals. The standard system can be used (Jung et al., 2013; McPherson \& Nunes, 2004; Sabad et al., 2014). The social definition paradigm (Jones, 2012) emphasizes actions based on subjective meanings. Good behavior tutors will positively repeat when getting the expected reward, on the contrary, non-repetitive behavior when the behavior of the person gives birth to a punishment that is greater than the reward. The repetition of a person's social actions such as a tutor is very dependent on the repetition or similarities that existed and were obtained in the past (James et al., 2011)

\section{CONCLUSION}

Based on the results of the discussion carried out on 3 proposed problems, it can be concluded: (1) The ideal form of tutor recruitment so that all teacher quality improvement programs are successful and run well is through tutor selection, through tutor candidate tests, through agency recommendations, through special offers. (2) The role of tutors in the professional learning process in tutorial activities undertaken is that tutors are still needed in the tutorial process for certain subjects by looking at the essence and level of difficulty and complexity of the course, as an innovator, the role of reducing dropouts and motivators. (3) To get a qualified Tutor so that becoming a Tutor at OU is not only as an additional job so that the tutor in working remains professional is to build a good system, between the obligations and rewards that are received properly, between taxes and reasonable income, between expertise or class rank needs adjusting for the level of reward given. 


\section{ACKNOWLEDGEMENTS}

Thank you to the Open University Indonesia for supporting and funding this research. Number: SP DIPA-042.01.2.400981/2019 Date 05 December 2018. According To Research Implementation Agreement Number: 12450/ UN31.LPPM/PM/2019 Dated March 13, 2019. Thank you for all respondent in this research.

\section{REFERENCES}

Belawati, T., \& Darojat, O. (2012). Open and distance education. UT Publishing Center.

Bogdan, R., \& Biklen, S. K. (1998). Qualititative research for education: An introduction to theory and methods. Allyn and Bacon.

Craig, A., Goold, A., Coldwell, J., \& Mustard, J. (2008). Perceptions of roles and responsibilities in online learning: A case study. Interdisciplinary Journal of E-Learning and Learning Objects, 4, 205-223. https://doi.org/10.28945/3205

Darojat, O., \& Belawati, T. (2014). Managing quality assurance in a mega university. Center for Learning Innovations \& Customized Knowledge Solutions (CLICKS), 1(5).

Darojat, O., \& Belawati, T. (2017). Quality assurance in open and distance education: A case of universitas terbuka, Indonesia. In C. Li, Open and Distance Education International Quality Assurance Case (pp. 19-28). Beijing Normal University Press.

Teguh. (2016). Duties and responsibilities of tutors in implementing Open University online tutorial (case study of mathematics education courses 2). In U. Kusmawan, A. Sapriati, T. Purwoningsih, S. Aisyah, Yumiati, Darminah, E. Wahyuningrum, S., \& Purnama (Eds.), Proceedings of the National Teachers' Scientific Meeting (TING) VIII. (pp. 238-246).

Anthony, G., \& Turner, J. (Eds.). (2015). Socially theory today. Pustaka Pelajar.

Harirotunnadhiroh. (2013, April 22). Functions and duties of tutors, facilitators in adult education. Harirotunnadhiroh. https://harirotunnadhiroh.wordpress.com/2013/04/22/ fungsi-dan-tugas-tutor-fasilitator-dalam-pendidikan-orang-dewasa/

James, R., Tynan, B., Marshall, S., Webster, L., Gordon. S., \& Lewis, R. (2011). Regulatory framework for distance education: A pilot study in the Southwest Pacific/South East Asia region. A final report. International Council for Open and Distance Education (ICDE). https://www.saide.org.za/resources/Library/ICDE\%20-\%20RegulatoryFrameworksfor DEfinalreport.pdf

Jung, I., Wong, T. M., \& Belawati, T. (Eds.). (2013). Quality assurance in distance education and elearning. Challenges and solutions from Asia. Sage Publishing.

Mead, G. H. (2012). Mind, self, society: The definitive edition (H. Joas, D. R. Huebner, \& C. W. Morris, Eds.). University of Chicago Press.

Meilani, A. (2008). A Portrait of Activation of Tutors and Students in Open University Online Tutorial: Case Study of Management Study Program-FE. Jakarta: Universitas Terbuka.

Miles, M. B., \& Huberman, A. M. (2012). Qualitative data analysis (T. R. Rohidi, Trans.). University of Indonesia Publishers.

Moleong, L. J. (2014). Metodologi penelitian kualitatif [Qualitative research methodology]. Remaja Rosdakarya.

Moore, M. G., \& Kearsley, G. (2012). Distance education: A system of view of online learning (3rd ed.). Wadsworth Cengage Learning. https:// doi.org/10.1080/00131911.2020.1766204

Muhajir, N. (2013). Metodologi penelitian kualitatif [Qualitative Research Methodology]. Rajawali Publisher.

Open University. (2015a). Open University strategic plan. 2015-2020. Karunika Open University Publisher.

Open University. (2015b). Profile of Open University making higher education open to all. Open University Publisher.

Open University. (2005). PGSD S1 tutorial guidelines. Open University Publisher.

Open University. (2016). Catalog of pendas program. Open University Publisher. 
McPherson M., \& Nunes, M. B. (2004). The role of tutors as an integral part of online learning support. The European Journal of Open, Distance and E-Learning (EURODL).

Jones, P. (2012). Introducing social theory. Yayasan Pustaka Obor Indonesia Yogjakarta.

Sabadie, J. M. A., Muñoz, J. C., Punie, Y., Redecker, C., \& Vuorikari, R. (2014). OER: A European policy perspective. Journal of Interactive Media in Education, 2014(1), Art. 5. http://doi.org/10.5334/2014-05

Salim, A. (2011). Teori dan paradigma penelitian sosial [Theory and paradigm of social sciences]. Tiara Wacana Publisher.

Siemens, G. (2005). Connectivism: A learning theory for the digital age. International Journal of Instructional Technology \& Distance Learning, 2(1), 3-10.

Simamora, L. (2003). E-Learning: Concepts and developments in technology that support it. In A. Durri (Ed.), Cakrawala pendidikan: E-Learning dalam pendidikan [Educational horizons: ELearning in education]. Open University Publisher.

Sugiran, Daulay, P., Zaman, B., Effendy, F., \& Amalia L. (2016). Evaluasi tutor online untuk meningkatkan kualitas layanan tutorial tatap muka pada pendidikan jarak jauh [Online tutor evaluation to improve quality of face-to-face tutorial services in distance education]. Journal of Information Systems Engineering and Business Intelligence, 2(10), 1-10.

\footnotetext{
Author (s):

Titik Setyowati

UPBJJ-UT Surabaya, Open University Surabaya,

Campus C Mulyorejo Unair 60115, Indonesia

Email: titikyowati@ecampus.ut.ac.id
}

Rahyu Setiani

Bhinneka PGRI University of Tulungagung,

Jl. Mayor Sujadi Timur No.7, Ploso Kandang, Tulungagung 66221, Indonesia

Email: rahyusetiani@gmail.com

Dwi Sambada

UPBJJ-UT Surabaya, Open University Surabaya,

Campus C Mulyorejo Unair 60115, Indonesia

Email: dwisambada@ecampus.ut.ac.id

Wuwuh A. Surasmi

UPBJJ-UT Surabaya, Open University Surabaya,

Campus C Mulyorejo Unair 60115, Indonesia

Email: wuwuh@ecampus.ut.ac.id

\footnotetext{
* Dwikoranto (Corresponding Author)

Department of Physics, Faculty of Mathematics and Natural Science,

State University of Surabaya,

Jl. Ketintang, Surabaya 60231, Indonesia

Email: $\underline{\text { dwikoranto@unesa.ac.id }}$
} 